\title{
Artists as Scholars: The Research Behavior of Dance Faculty
}

\author{
Shannon Marie Robinson
}

The research behaviors and library use of dance scholars are widely unknown, particularly in regard to issues of access to historical materials and new technology preferences. In the past thirty years, college and university dance departments in the United States have developed into independent, research-based programs. Despite the lack of current research examining the information needs of dance scholars, academic librarians must support the performance, research, and pedagogy of these programs. Interviews with dance faculty from three diverse institutions of higher education provide exploratory data about these scholars' research needs. This qualitative study provides context for dance faculty experiences as both artists and teachers.

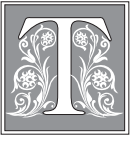

he academic discipline of dance has a relatively short history. Dance was first accepted in higher education through an association with physical education. Eventually the discipline became aligned with the arts, particularly music and theater. Given the brief history of dance as an academic endeavor, there is a corresponding lack of information about dancers and their research needs.

To understand the information needs of dancers in higher education, dance faculty from three universities were interviewed about their information-seeking practices and research needs. These interviews provide exploratory, qualitative data about these scholars' research experiences. Because many academic librarians charged with liaison responsibilities to dance departments do not have backgrounds in dance, the results of this research project will enable them to keep current on dancers' information needs and desired services.

\section{History of Dance in Higher Education in the United States}

According to Thomas Hagood in his comprehensive text on dance in higher education, "Dance, arguably the first of the arts, was the last to enter the realm of structured learning," doing so only through an association with physical education. ${ }^{1}$ While the University of Wisconsin-Madison first recognized dance as an academic discipline (within the department of Physical Education) in 1926, it was the formation of Bennington College in Vermont in 1932 that shaped dance education. Bennington's faculty was composed of dancers including Martha Graham, Doris Humphrey, and Hanya Holm. ${ }^{2}$

Shannon Marie Robinson is Liaison Librarian, Media Arts E Design, at Drexel University; e-mail: smr87@ drexel.edu. (C) 2016 Shannon Marie Robinson, Attribution-NonCommercial (http://creativecommons.org/ licenses/by-nc/3.0/) CC BY-NC. 
Just a year earlier, the American Physical Education Association formed a National Section on Dancing, the first national organization for dance educators. ${ }^{3}$

During the 1930s through 1950s, most dance programs continued to be part of physical education departments that may or may not have made a strong commitment to the subject. ${ }^{4}$ Dance as an artistic practice was often forced to compete with sports and exercise. Dance educators worked within academia to realign their programs with the arts, particularly music and theatre. However, at the 1964 Conference of the National Council on Arts in Education, dance professionals developed a Statement on Dance to reflect their desire for program independence. Dance educator Gertrude Lippincott quoted from the Statement in a 1965 article: "While dance can contribute to music, theatre, and physical education, to function most effectively at the several educational levels in today's expanding program of the arts in education, dance needs to be free from the administrative subordination to the other professional fields." ${ }^{5}$

A national interest in expanding arts education led to the establishment of the National Endowment for the Arts in 1965. In the early 1980s, the National Association of Schools of Dance (NASD) formed as the national accrediting agency for dance. The remaining years of the twentieth century saw a surge in dance education as the number of academic dance departments, and the number of students in those departments, skyrocketed. The National Center for Educational Statistics' College Navigator currently lists 295 American colleges or universities with some type of dance program. ${ }^{6}$ These dance programs educate students as practitioners, choreographers, teachers, historians, and theorists.

Today, dance is a multidisciplinary and multicultural practice. Dance scholarship and practice embodies history and religion, race and ethnicity, gender and sexuality, biology and neuroscience, and visual and performing arts. Contemporary dance students are required to be at home in the studio, classroom, and computer lab.

\section{Literature Review}

The only comprehensive study on the information needs of dancers is a 1996 thesis by Kent State University graduate student Dawn M. Grattino. ${ }^{7}$ She surveyed Ohio dance professionals, including faculty, students, dance administrators, and freelance dancers, about resources and subject matter frequently used in their working environment. The most frequently used information source was colleagues; books, journals, videos, and music were also heavily consulted. ${ }^{8}$ Dance techniques, choreography, and the creative process were the most used subjects. ${ }^{9}$ Use of technology was limited; 30 percent of respondents never used a personal computer and 37 percent never used the Internet. ${ }^{10}$ Since Grattino's survey, technology formats have changed and the Internet is much more accessible. Sites like YouTube and electronic databases like the International Bibliography of Theatre \& Dance have vastly changed the way dance scholars access and store information.

Since dance often includes stage production and music, the information practices of dancers may be similar to those of theatre practitioners and musicians. For example, in her findings from a survey of theatre artists, Ann Medaille states that collaboration is instrumental in production so "it is not surprising that theatre artists are continually turning to personal contacts and professional networks to provide them with needed information and resources."11

In Francesca Marini's twenty-two interviews with theatre scholars, twenty of the participants were faculty. ${ }^{12}$ From these interviews, she devised categories of theatre research that "encompass the specific issues addressed by the scholars": context, time, creativity, engagement, and interdisciplinarity. ${ }^{13}$ MaryBeth Meszaros surveyed theatre scholars, the majority of whom were faculty, and discusses the scholars' barriers to 
archival research because so many resources are still not available online. ${ }^{14}$ Bonnie Reed and Donald Tanner, surveying faculty in visual arts, music, theatre, and dance, found many faculty preferred to "build their own collections" in conjunction with using the university library. ${ }^{15}$ Theatre and dance faculty ranked books as the most important resource for their research and highlighted the importance of seeing live performances and attending conferences. ${ }^{16}$

Research exploring the information needs and format preferences of performing arts students may also be useful. Kirstin Dougan has researched the information needs of undergraduate and graduate music students. ${ }^{17}$ Katie Lai surveyed undergraduate music students' use of YouTube and the library's multimedia collection, finding that students preferred YouTube when preparing for a music lesson or rehearsal, but favored the library's multimedia collection when writing academic papers. ${ }^{18}$ Joe Clark surveyed music, dance, and theatre students about their format preferences for various resources. ${ }^{19}$ Dance majors showed strong interest in having DVDs and CDs added to the collection. ${ }^{20}$

A few studies examine the research needs of performing arts faculty. Christine Brown interviewed music faculty to develop a model of the music scholar's research process, from idea generation to dissemination. ${ }^{21}$ Katie Lai and Kylie Chan surveyed music students and faculty, finding that faculty used online music sources significantly less than students. ${ }^{22}$ Chern Li Liew and Siong Ngor Ng interviewed faculty ethnomusicologists and found that the common practice of academic libraries cataloging CDs by accession (rather than genre) prohibited browsing and discovery. ${ }^{23}$ They also noted that copyright restrictions were problematic for some faculty, both by prohibiting access to other scholars' research and in making their work available to others. ${ }^{24}$ Kirstin Dougan surveyed music faculty and librarians about their use of YouTube, finding that faculty use the online video-sharing website in their teaching and research, including uploading their own content. ${ }^{25}$ She concludes, "even though some faculty advocate for how much better/more powerful library catalogs are than tools like YouTube, faculty overwhelmingly find YouTube to be easier to use than library catalogs." ${ }^{26}$

\section{Methodology}

Thirty-five dance faculty from three institutions of higher education were contacted via e-mail. The group of faculty selected for contact comprised varying levels of teaching experience and included text-based scholars and performance artists who represent a broad range of interests and dance methodologies. The University of the Arts, offering education only in the visual and performing arts, in Philadelphia, Pennsylvania, has one of the largest undergraduate dance programs in the nation. In 2014, fifty-five bachelor of fine arts degrees in dance were awarded, making it the university's most popular major. ${ }^{27}$ The Ohio State University is a public research university in Columbus, Ohio. The university is a founding member of the National Association of Schools of Dance and one of the first schools to award undergraduate, master, and doctoral degrees in dance. ${ }^{28}$ Denison University is a small, private undergraduate liberal arts college in Granville, Ohio. While offered as a major, most students enrolled in dance courses are nonmajors and likely being exposed to dance for the first time.

Of the thirty-five faculty initially contacted, in-depth interviews with twelve dance faculty were conducted during the winter of 2014-2015: five from The University of the Arts, four from The Ohio State University, and three from Denison University. Two men and ten women were interviewed. Faculty rank includes three professors, one associate professor, three assistant professors, three adjunct associates, and two lecturers. Five faculty members have PhDs, six have MFAs, and one has no post-secondary education. The length of teaching in higher education ranges from two years to more 
than thirty-five years. Few of the faculty interviewed self-identify by their academic title; they prefer titles including dance scholar, choreographer, dancer, performance artist, teaching artist, and artist scholar. Six faculty members conduct primarily textbased research and scholarship and six faculty primarily engage in performance-based research and scholarship.

Hour-long interviews were conducted in person or via Skype and were recorded. Open-ended questions were asked of the faculty about their current research projects, the subject matter most often used in their work, how they stay current with the larger dance world, others who advise or assist them with their work, format and access preferences for resources, how they manage information, how their research process might be improved, and what role the library could play in supporting their research (see appendix).

This research is limited in size and scope, as only twelve dance faculty members at three schools were interviewed. Therefore, the findings cannot be generalized. This study is intended to be exploratory, beginning to fill a gap in the information science literature. Despite limitations, the qualitative findings give insight into the research process of academic dance scholars.

\section{Findings}

\section{Descriptions of Current or Recently Completed Research Projects}

The faculty members were asked to describe a recently completed research project or one on which they are currently working. Faculty were encouraged to openly interpret "research," and many provided examples that suggest a broad definition of the term. The variety of answers demonstrates the complexity of the dance discipline and the diversity of research being conducted.

Choreographers and dancers are creating a number of movement-based works. Dances include an ongoing performance that has expanded from a solo to an eveninglength work; a feminist performance drawing from experiences with menstruation and sexual violence; a collaborative project with both visual and performing artists about how white supremacy is linked to violence against the black body; and a solo work about sacrifice, derived from an investigation of Judaism. One scholar is beginning a residency where she will create a new performance with dancers who have shared a lifelong common geography; all have lived in Florida and New York City. Two faculty members are creating new repertoires with student dancers at their respective institutions, and one faculty is creating a dance student exchange program between the United States and Africa.

The nonperformance scholars, who are focused on dance history, criticism, and digital humanities among other scholarship, are creating books, articles, and multimedia tools for education and research. Book-length works include a history of the somatics movement and its relationship to both the civil rights and women's rights movements; an examination of British ballet during World War II; an exploration of dance in online environments, particularly social media and popular culture; a biography of American choreographer Anna Sokolow; and an inquiry into the relationship between literacy and dance. Other projects include interactive websites examining dance structures and notation; an iPad application for dance movement notation; and an online mapping system charting the touring pathways of dance companies.

\section{Subject Matter}

The faculty members were asked which subject matter they used most often in their work. Subjects within dance and from other disciplines were mentioned (see figure 1). The most popular dance subjects are choreography, mentioned by half (50\%) of the 


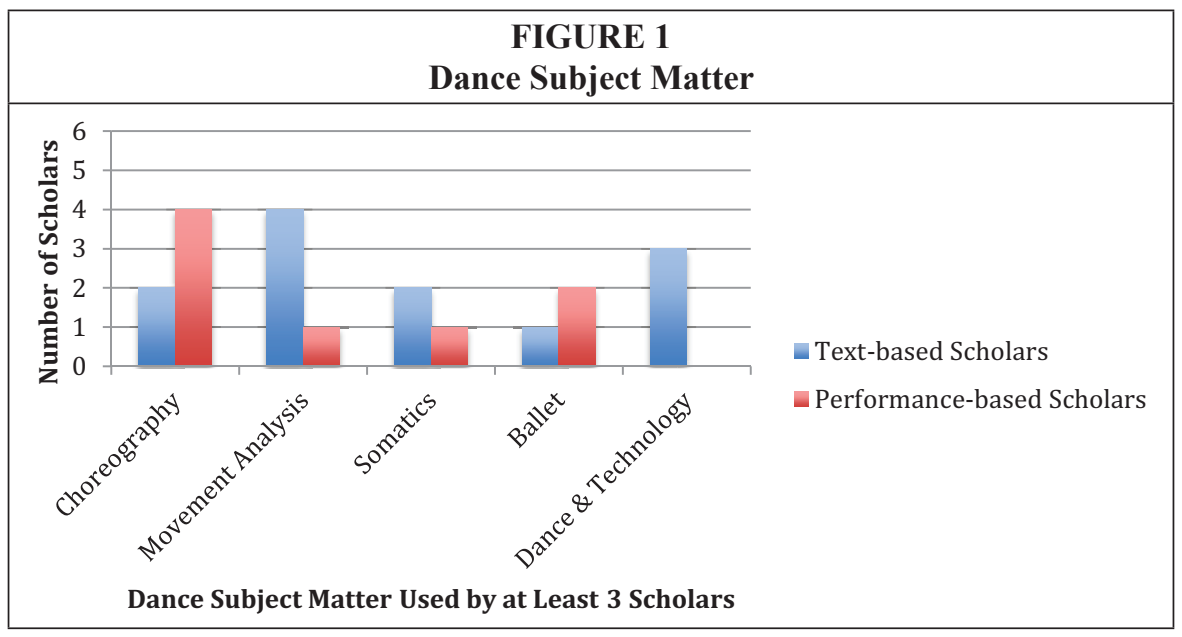

faculty, and movement analysis (42\%). Choreography includes looking at individual choreographers like Deborah Hay, Ralph Lemon, or Merce Cunningham, as well as considering "how choreography tells us things about the world in which we live." 29 Movement analysis describes the Laban Movement Analysis, a popular method of documenting movement derived from the work of dancer Rudolf Laban. Bartenieff Fundamentals, a movement analysis derived from Laban, is also an important dance subject of study for these scholars. Other dance subjects referred to by at least 25 percent of faculty include somatics and mind/body centering, ballet, and the interplay of dance with technology.

In regard to other art subjects used by the faculty members, visual art is most heavily used, mentioned by 42 percent of faculty (see figure 2). Music is mentioned by 25 percent of the faculty, and none mentioned theatre. Two faculty members specifically mentioned performance art or movement-based work created by artists who are not considered dancers. Two scholars cite film as an important subject for their work.

Outside the visual and performing arts, language and literature is an often-used subject, listed by 58 percent of faculty. This category includes poetry, fiction, autobiographies of dancers, and the study of literacy. Two scholars discussed how dancers

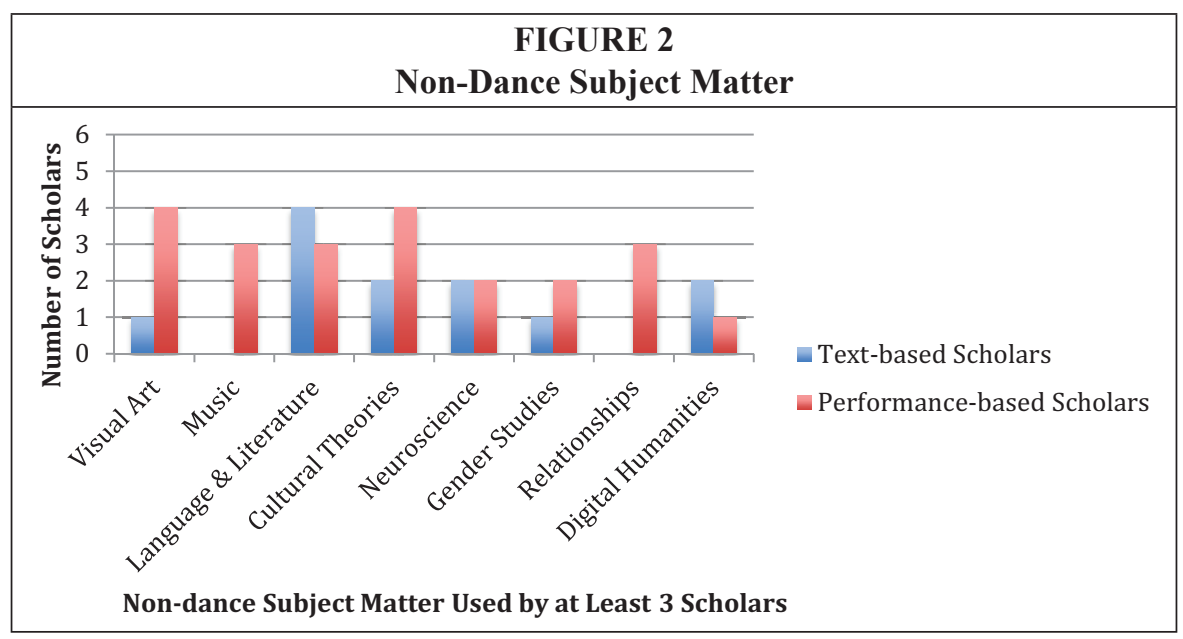


must learn about the languages of other disciplines because dance relies heavily on other disciplines, particularly those in the sciences. One faculty member said, "I want dance research to be bridged to a world wider than dance," and this requires dance scholars to understand the language and literature of other fields. ${ }^{30}$

Other subjects used in their work include cultural studies and theory (50\%), neuroscience $(33 \%)$, gender studies (25\%), human interactions and relationships (25\%), and digital humanities (25\%). Two scholars each also mentioned history, environmental design, and religion.

\section{Staying Current in Dance}

Faculty were asked what information sources they frequently consult to stay current with the general dance world (see figure 3). Faculty were encouraged to discuss any source that kept them informed of trends and new research in their chosen field. The most used source, cited by 67 percent of the scholars, is people, specifically peers within a faculty member's institution and other artists. A choreographer said that being connected to an academic institution means "you are in a community of colleagues who are somehow deeply connected to dance." ${ }^{11}$ These communities are also formed by geographic location. Living in New York City helps three of the performance-based faculty members connect to other artists. Travelling is another way to extend one's network; six faculty members mentioned this as a way of staying abreast of new ideas in dance.

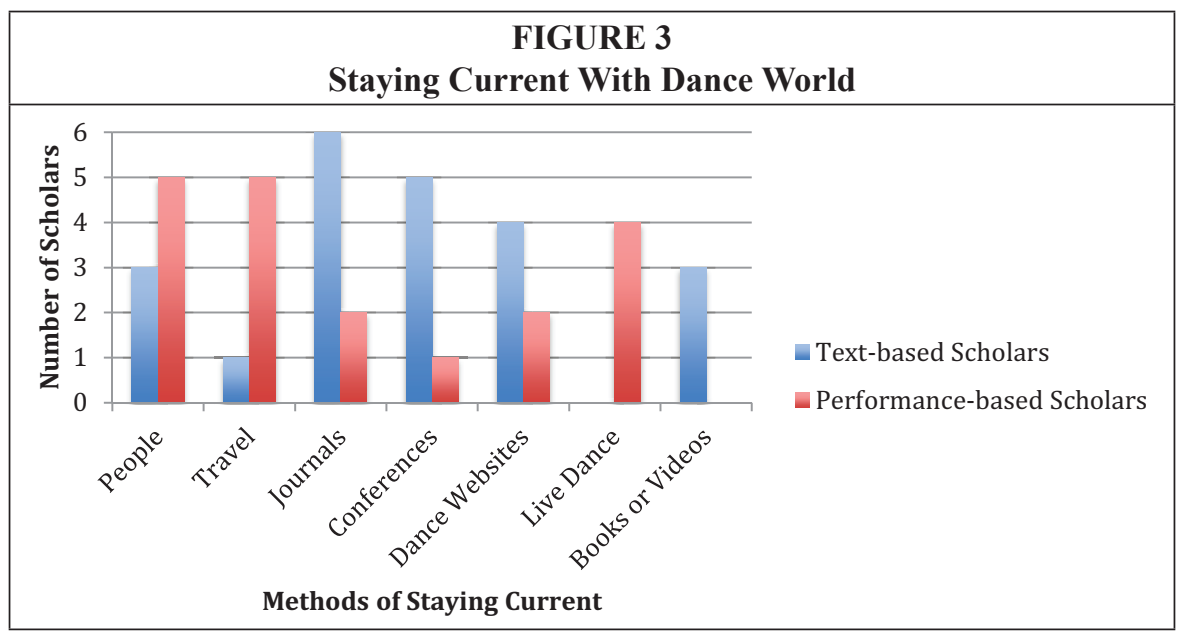

Journals were mentioned by eight of the twelve respondents as a source for staying current. Journals discussed by more than one faculty member include Dance Research Journal, Dance Chronicle, The Drama Review, and Contact Quarterly. Access to these journals is often tied to personal memberships to dance organizations. For example, the Congress on Research in Dance publishes Dance Research Journal, and four of the scholars are members. For publications not associated with a membership, these faculty members both personally subscribe to journals and also choose to access journals through their academic library.

Another source of current information is also connected to dance organizations - 50 percent of faculty regularly attend conferences and workshops. Visiting websites of individual choreographers or dance companies is employed by 50 percent of respondents. Four of the faculty, three of whom are partly based in New York City and all of whom are performance-based scholars, cite watching live dance as a source of staying 
abreast. Books and videos are used less frequently (25\%) for keeping current with the general dance world.

\section{Getting Advice or Assistance}

When asked about the people who advise or assist them with their research, 50 percent of respondents say colleagues, either within a faculty member's institution or at another academic institution, are the most consulted. Four of the six faculty primarily engaged in performance-based practices cited the dancers in their pieces as advisors. Two respondents stated that they seek feedback on their work from artists in other disciplines. Only one faculty member, who does text-based research, mentioned seeking assistance from both an academic librarian and an archivist.

The preferred method of engaging with these mentors and assistants is face-to-face contact; 83 percent of the faculty say they prefer in-person conversations. Forty-two percent of respondents also stay in touch through Facebook, 33 percent regularly use e-mail, and 25 percent use Skype. Only one faculty member mentioned using the phone to keep in contact with advisors.

\section{Material Format Preferences and Library Material Use}

Direct questions were asked about the faculty members' preference for accessing print and electronic resources. The questions focused on book, article, video, and music formats. All twelve scholars prefer print books to electronic books. They cited qualities like tactility (33\%), the ability to flip through pages (25\%), and the ease of note-taking on the page $(25 \%)$ as reasons for using print books. Faculty readily expressed frustration with electronic books. They mentioned issues with e-books including trouble reading on a computer screen $(25 \%)$ and the limitations of multiuser access $(17 \%)$. Speaking about e-books provided through the subscription-based digital library e-brary, a researcher said, "I don't find it user-friendly at all" and that the user interface is ugly; "aesthetics are actually important to me!" she emphasized. ${ }^{32}$ When consulting articles from journals and magazines, the faculty all prefer to access the articles online. However, when reading the articles, they are evenly split in their preference; six of the scholars print the article and read offline while six read the article online.

Format preferences for video were straightforward (see figure 4). Ten of the twelve faculty use YouTube as their primary source for finding videos. As one faculty member stated, "Don't discount YouTube...it's changed our lives [and] changed our teaching."

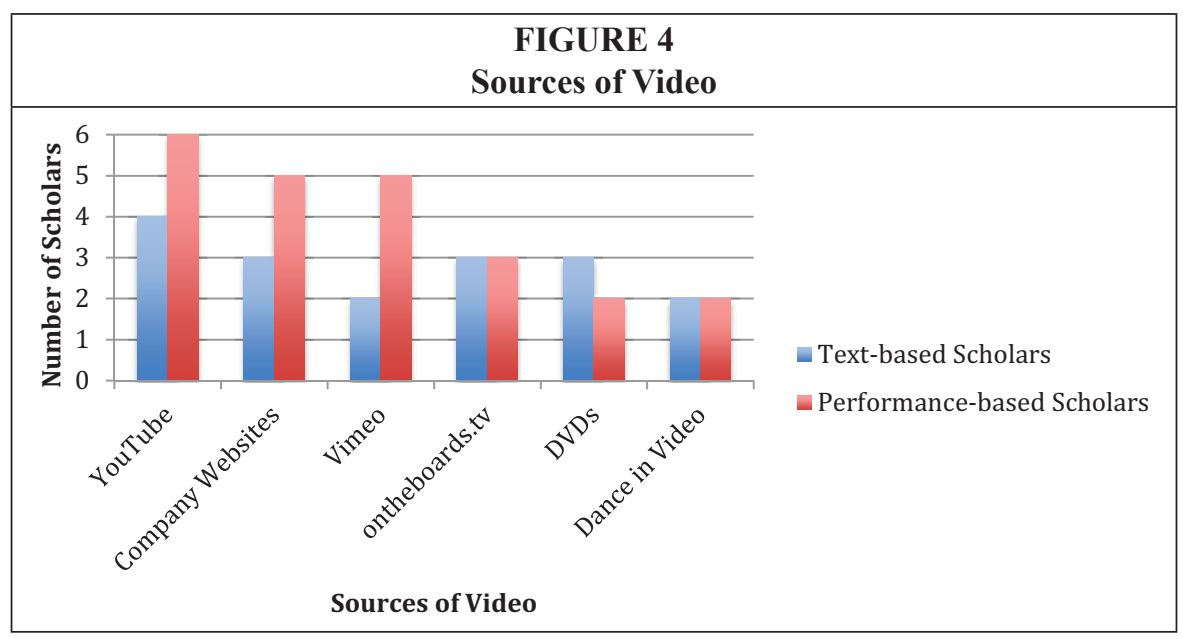


The two scholars who do not regularly use YouTube cited the impermanence of videos on the site; videos are continually removed from the website, usually for copyright infractions. Additionally, many of the dance videos on YouTube are not full-length recordings of a performance.

Faculty also watch video from a variety of other websites, including dance company websites, mentioned by 67 percent of respondents; Vimeo (58\%); ontheboards.tv, the subscription streaming video database available through the libraries at The Ohio State University and The University of the Arts (50\%); DVDs (42\%); and Dance in Video, the subscription streaming video database from Alexander Street Press, available at all three academic libraries (25\%). One faculty member stated her dislike of Dance in Video because she found the video to not always be full-length performances or of poor quality. Another faculty member said she does not use the subscription databases "because if I'm going to write about something, I want my reading audience to have access to it." 34

Most faculty have multiple methods of accessing music during their research process (see figure 5). Fifty-eight percent use iTunes, 42 percent use CDs, 42 percent use live musicians (for performances), and 25 percent rely on Spotify, free software for listening to streaming music. Two faculty members mentioned that they access music solely on their smartphones. "Everything is on my phone. I just play from that," said one choreographer. ${ }^{35}$ No one mentioned YouTube as a source for music, and only one faculty member uses the subscription streaming audio database Naxos Music Library. Faculty discover new music through friends and colleagues; this is particularly helpful for the three faculty who mentioned that searching for music is difficult.

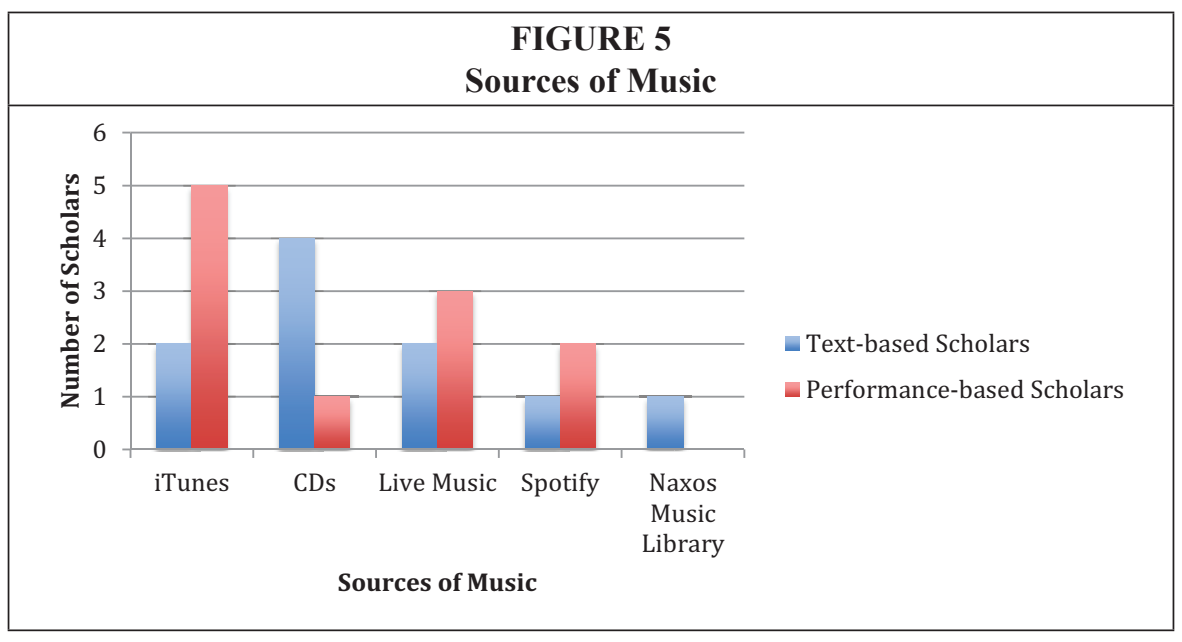

In discussing access to resources, especially video and audio, the performance-based faculty expressed confusion about and frustration with copyright. Choreographers and dancers are not always paid for their work, or paid very little, making it difficult to pay for royalties. For example, one choreographer has had her performances removed from YouTube because of copyright infringements from using music without permission. They want to share their work but often will not because they are so concerned with infringing copyright and intellectual property laws. Faculty are also concerned about distributing their own work and having it stolen. 


\section{Managing Information}

The scholars were asked to discuss their methods for managing the information needed for their research. Ten of the twelve faculty have personal book collections; they often buy any book they will use more than once in either their research or teaching. Many faculty talked about borrowing books from colleagues and relying on these colleagues for reading recommendations. Three faculty, all choreographers, stated that they use their dance department's book collection rather than using the university or public library. The faculty members store other printed material, including articles and research notes, in horizontal filing systems (25\%), notebooks $(17 \%)$, or notecards $(8 \%)$. For managing electronic information, particularly PDFs of articles, 50 percent of the faculty have files stored on their desktop computer and 33 percent use an external hard drive for backing up their files. Video files are stored a number of ways. Two respondents use DVDs to save videos and two others have personal subscriptions to Vimeo that includes storage space; one of them also has private files stored on YouTube. Another faculty member uses KeepVid, a free application that allows you to download video from the Internet. Audio file storage includes iTunes (25\%) and CDs (8\%).

\section{Navigating the Research Process}

The faculty identified four issues that either frustrate or prohibit their processes: time and money restrictions, having to rely on others, searching for the unknown, and copyright issues. Time and money restrictions were mentioned by 33 percent of the faculty. "I would love to not have to work all summer," one adjunct faculty member said. ${ }^{36}$ Other adjunct faculty who cannot financially afford to take any time off from teaching to exclusively focus on research echoed this sentiment. Two adjunct faculty mentioned having no permanent space on campus and a high volume of students as deterrents to research activities. This impacts their library use, particularly onsite. "Even something like returning a book can become difficult," said one adjunct faculty member. ${ }^{37}$ Three faculty members mentioned that traveling for research purposes is a burden on both time and finances.

Four of the twelve faculty mentioned that there are both benefits and disadvantages to working with other people during the research process. One faculty member focused on other dance scholars who don't seem computer savvy; these scholars are unable to use platforms such as Skype or Google Hangouts, so the faculty member must travel for in-person meetings. Three faculty discussed having to ask for assistance to find information. One scholar enjoys working with archivists and librarians because they show her relevant, related materials that expand her research. However, two other scholars said they do not like to ask for help; one mentioned that she will take a friend's recommendation rather than seek a librarian's assistance.

Most of the faculty feel confident using search tools to find known items; however, three faculty discussed frustration in using search tools to browse or discover new information. "I don't even know what I would search for to find something new that I wasn't specifically looking for," said one choreographer. ${ }^{38}$ Another researcher mentioned needing to know exactly what you want in order to find it, and yet another faculty member wondered if she'd ever find books without already knowing titles.

Finally, 25 percent of the faculty again brought up copyright issues regarding access to dance resources. "We privilege that live experience," said one scholar, noting that this hurts historical scholarship by not having good records of past performances. ${ }^{39}$ Faculty members want freely accessible video of full-length performances. Another scholar who does a lot of archival research brought up issues of access to performance ephemera. She is frustrated by "how many hoops you have to jump through just to see this material" and how much it costs to ensure proper permissions for publication. ${ }^{40}$ 


\section{Perceptions of Library's Role in Supporting Research}

A final question was asked about what role libraries might play in supporting dance faculty research. Responses can be generalized into four areas: more online access, new resources, better organization of resources, and research support. Three faculty members said they want more online access to all types of resources and another three faculty specifically mentioned more online access to video. The Internet has driven this desire for online access. One faculty said she wants to be able to find everything, library resources and free web resources, through a Google search. Faculty again mentioned video sites like YouTube and Vimeo. They want freely available and easily searchable video databases with more contemporary and nontraditional dance.

Half of the faculty members would like for libraries to offer new resources. New resources mentioned include electronic access to journals and newspapers that are not indexed in the subscription article databases, digital humanities tools, and videos of street and nightclub dancing. Faculty also want the archives of choreographers to be more readily available. They expressed a need for different types of books, particularly those that deal with the business elements of dance and how-to guidebooks with dance exercises and techniques.

Faculty members desire a better-organized library, particularly in regard to cataloging. Thirty-three percent of scholars discussed some sort of organization issue, saying that library systems are not intuitive. With regard to libraries' cataloging systems, one faculty member said, "I don't like the silo-ing of the arts stuff," where the visual arts material is separate from dance. ${ }^{41}$ The scholar felt that this makes it difficult to browse, especially since she is interested in artists who cross disciplines. In using the online catalog, another scholar mentioned the advantages of Amazon's search interface, which includes the option to view a book's table of contents and book reviews. This scholar is aware that many library catalogs offer these tools, but she feels they are not userfriendly or well designed. A third faculty member pointed out that a lot of cataloging work, particularly in archives and special collections, is being done in-house. This means each time this researcher goes to a catalog, she is confronted with a new system. She wants to see all these in-house catalogs cross-linked with one search interface.

Half of the faculty members considered the assistance of librarians and archivists to be the most important role libraries might play in their research process. Some faculty mentioned already having collaborative relationships with library staff. One researcher admitted she wasn't expecting to find librarians willing to be partners on her project; she has been surprised by the continued support. Another faculty member says she makes an effort to introduce herself to librarians and archivists because she finds their assistance on projects so important. One faculty member said she has found librarians to be "pretty radical thinkers" who help her get outside her "filter bubble" and discover new information. ${ }^{42}$ Another said librarians help her "make connections between things." 43

However, not all of the faculty members have yet made a connection with librarians. Performance-based scholars were less likely to mention librarians as playing supportive roles in their research process. This is largely because practitioners do not view the library as a place for inspiration or serendipitous discovery. One choreographer felt certain that her method of working "isn't really gelling or intersecting with the work that you do in the library." ${ }^{44}$ Additionally, these scholars' time is divided between teaching and performing, leaving them little time for visiting the library or consulting with a librarian. For instance, another performer said he would love to e-mail a librarian with a research topic and get recommended resources. He then immediately stated, "But as soon as I say that, I just go to Google. I'll just see what's right here instead of adding that extra administrative layer onto it." ${ }^{45}$ As more resources are available online 
and quickly found through a keyword search on Google, some faculty see less need for librarian assistance in their research process.

\section{Discussion}

These exploratory interviews demonstrate that dance scholars' research behaviors are similar to that of theatre artists. Ann Medaille ${ }^{46}$ and Michael Olsson ${ }^{47}$ both found theatre artists rely heavily on sharing information with collaborators during the production process. This emphasizes what most of the dance scholars stated: their peer network is the most relied-upon resource. Dance faculty, regardless of their research output, value face-to-face discussions with their peers and often rely on this network to provide recommended reading.

Librarians need to become established members of this network to better serve dance faculty. In the interviews, the faculty stressed the importance of attending conferences and workshops as a way to stay current with trends in dance. This reiterates their desire for a strong, in-person network. Performing arts librarians should consider attending dance-specific conferences. In 2013, ${ }^{48} 2014,{ }^{49}$ and again in $2016,{ }^{50}$ the Society of Dance History Scholars and The Congress on Research in Dance have held joint conferences. These conferences are opportunities for librarians to learn more about the various subdisciplines in dance while making valuable connections with faculty.

In her theatre study, MaryBeth Meszaros found a distinction between theatre academics and stage practitioners. She noticed "the theatre practitioner need find only what 'works' for the audience. In contrast, the theatre academic, writing an article for publication, is held to standards that are much more objective." ${ }^{15}$ Olsson states a similar finding in "the relative lack of importance [practitioners] attached to purposive information seeking." ${ }^{2} 2$ The interviews with both text-based academics and performancebased scholars suggest a similar perception among dance faculty. Performance-based faculty are less likely to have a common research process and are less careful about documenting that process. Additionally, Medaille ${ }^{53}$ and Meszaros ${ }^{54}$ both found a lack of time on the part of practitioners to impede their research process. Performance-based dance scholars echoed this sentiment, especially those faculty with adjunct status.

As part-time faculty lines become the norm in academia, librarians must find new ways of distantly connecting with dance faculty, particularly choreographers and dancers. All of the performance-based scholars traveled frequently, often weekly. Many perform in locations outside their teaching institutions, usually in other states or even other countries. Offering services such as chat reference or virtual research consultations can help librarians stay in touch with dance faculty while they are off campus. Additionally, providing these services on evenings or weekends may help with outreach to faculty who divide their time between the classroom and the stage.

In relation to faculty use of YouTube, the findings are comparable to Kirstin Dougan's study of YouTube use by music faculty. ${ }^{55}$ She found that faculty are posting their own work to the streaming video site, are using the site to teach, and find it overall more convenient than using a library collection. Sites like YouTube and Vimeo, along with new modes of streaming audio and video, have greatly changed how performance scholars conduct research and share information. Though copyright continues to be of some concern, the ease of access outweighs most faculty members' hesitation to embrace these new websites and streaming services.

When asked to self-identify, many of the faculty referred to multiple statuses; for example: "somatic ethnographer," 56 "choreographer/performer," 57 and "teaching artist." 58 Dancer Veronica Dittman calls contemporary dancers " slash' artists." ${ }^{59}$ The need for both a wide range of experience and the fiscal chore of holding multiple jobs to make ends meet means performers can no longer think singularly about their career. 
As stressful as this is, Dittman sees value in decentralization. This breadth of experience and interest stems "from the fact that most of us came through good university dance departments within decent liberal-art programs" and were exposed "to writing, technology, history, kinesiology, and somatics from within our departments as well as other strong interests we may have developed elsewhere in the university." ${ }^{\prime 60}$ Relying on numerous ways to describe their careers indicates a bent toward interdisciplinary work.

In Francesca Marini's interviews with theatre scholars, librarians, and archivists, she grouped her findings into broad categories; the last of these is interdisciplinarity. She observed that the scholars have "different educational backgrounds, have different interests and research problems, use tools and methods from different disciplines, merge disciplines together in order to develop new approaches and solutions to problems, work with artists and scholars from other fields, and operate across cultures." ${ }^{61}$ This nicely summarizes results from the interviews with dance faculty, suggesting a closer examination of interdisciplinarity as a lens through which to view current dance research practices. Jan Van Dyke from the dance department at the University of North Carolina wonders if "perhaps we should not be evaluating new kinds of work with old standards." 62 As dance embraces new disciplines and methods of performing, our notion of dance must broaden.

Interestingly, twenty years ago Marcia J. Bates noted two types of scholars lacking examination within information science: performing artists and interdisciplinary researchers. ${ }^{63}$ In his study of interdisciplinary faculty, Don Spanner noted that art professors tended to be more involved in "fringe" research than those in other disciplines. ${ }^{64}$ Overall, he found that interdisciplinary scholars had issues with language, having to learn the vocabularies and culture of more than one discipline. ${ }^{65}$ Issues with language and methodologies across disciplines were mentioned by some of the dance faculty interviewed. Spanner also found that border-crossing faculty felt the need to attend more conferences to keep up with new developments. ${ }^{66}$ The dance faculty rely heavily on conference attendance and proceedings. All of these similarities suggest a strong correlation between the research practices of dance scholars and those faculty who consider themselves interdisciplinary.

The results of the interviews indicate that dance faculty are frustrated with traditional library cataloging and want more chance encounters with new ideas through library search tools. One of Bates' suggestions for how librarians can support interdisciplinary work is through "one-stop searching." ${ }^{67}$ Likewise, Jeffrey Knapp states that libraries "must develop methods to allow online users to serendipitously discover relevant materials" outside their dominant discipline. ${ }^{68}$ Online methods of multidisciplinary research have become commonplace with the advent of discovery layers and crossdatabase searching options. However, faculty may be unaware of how to use these Google-like tools to expand their research boundaries and make new discoveries. Dance librarians should offer individual consultations or workshops that demonstrate the potential of these tools.

In addition to discovery search tools, dance faculty want better access to archival material. As noted earlier, performance-based scholars are not as concerned with documenting their research process. However, when other scholars attempt to study these performances, they are left with little information. "Because of the ephemeral nature of dance, much of the history and documentation of the field exists not in books" but in one-of-a-kind materials such as notation, rehearsal videos, costume design sketches, and e-mail exchanges. ${ }^{69}$ Librarians and archivists should work directly with performance-based scholars to stress the importance of fully documenting their creative research process. Eugenia Kim's digital preservation toolkit could help dance faculty preserve their creative process. ${ }^{70}$ 
Bates concludes that interdisciplinary scholars "have to engage in both substantially more information seeking - and of a different kind - than scholars in a conventional discipline." ${ }^{71}$ Both Bates ${ }^{72}$ and Knapp ${ }^{73}$ mention selective dissemination of information as a way that librarians can assist interdisciplinary scholars in keeping up with new information across multiple fields. As dance librarians learn about the cross-disciplinary work of their faculty, they can create specialized literature reviews and suggest new materials in nondance disciplines. Knapp also advocates for allowing users to tag items in a library catalog to "provide better findability to interdisciplinary materials." ${ }^{\text {"74 }}$

\section{Conclusion}

Grattino concluded her research into the information-seeking practices of dancers by calling for further study of the needs of this unique user group; twenty years later, this research addresses her recommendation. ${ }^{75}$ These findings demonstrate both similarities and differences between text-based and performance-based dance faculty. Librarians must be cognizant of these two types of scholars. Understanding the research practices and subject interests of each faculty member will help librarians and archivists target their outreach in ways that will be most useful to those individuals. Additionally, considering the complexity of the dance field, librarians and other information specialists should consult the literature on interdisciplinary scholars' information needs for new ideas about how to support and engage with dance faculty.

The data gathered from these interviews will be of value to librarians as they determine collection development practices and user services for their particular dance and performing arts programs. However, as mentioned earlier, this research is limited and the findings cannot be generalized. While this study helps academic librarians begin to understand the research process of dance faculty, further research is needed to make broader conclusions. One potential study would be related to the consideration of dancers as interdisciplinary scholars rather than just performance artists. A fuller comparison of the two types of scholars may provide more data about how librarians might best serve dancers' information needs. Additionally, as technology and copyright change, dancers' needs will change. We must continue to explore this academic user group through more interviews, surveys, and focus groups to best meet their research needs.

\section{Acknowledgements}

Thanks to Sara J. MacDonald, Public Services Librarian at The University of the Arts, and Alan Green, Head of the Music/Dance Library at The Ohio State University, for their insight and support of this project. A 2013 Academic Library Association of Ohio Research and Publications Committee Research Grant funded this project. 


\section{Appendix. Interview Questions}

Open-ended questions were asked of all dance faculty. Guiding questions were asked to prompt conversation or clarify a response.

1. Please describe a project on which you are currently working or recently completed.

guiding: What is the general idea of the project? What was the inspiration? Is this a typical project for you? Tell me about the information you needed to do this project and how you found that information.

2. What subject matter do you use most often in your work? Which disciplines not related to dance/movement do you typically use for inspiration or research? guiding: Do you look for information on choreography, history, technique, pedagogy, theatre, music? What subjects not directly related to "movement" do you frequently refer?

3. How do you stay current with the general dance world? Are there other information sources you frequently consult in specific areas of interest? guiding: Which magazines, journals, blogs, websites, and/or specific authors do you frequently read?

4. Do others advise or assist you with your work?

guiding: Colleagues, mentors, librarians; what is your method of contact and conversation? E-mail, listserv, face to face?

5. The next few questions refer to your preferences for using information when it is available in multiple formats.

a. Do you prefer traditional printed books or e-books?

b. When consulting other sorts of traditional print materials, such as newsletters, magazines, and journals (articles), do you prefer consulting these in printed form or in electronic form?

c. Do you prefer watching dance-related videos using DVDs, or do you prefer online video sources?

d. guiding: Do you watch videos on YouTube or Vimeo? Have you ever used a library subscription video service such as Alexander Street Press' Dance in Video? Do you watch video from specific types of websites, such as dance companies?

e. When you listen to music (or work with music for preparing a dance production), do you use CDs or online streaming audio sources? guiding: Do you use services such as Spotify? iTunes? Have you ever used a library subscription music service such as Naxos Music Library or Alexander Street Press' Classical Music Library? guiding (for those using music for choreography or video): When preparing music for a choreographic project, what is your process? Do you use music from CDs or iTunes (or another online site)? Which software programs do you use to edit the audio files?

6. How do you manage or store the information that you have obtained? guiding: How do you keep track of the information you've found useful to your work? Do you have a personal library of books, articles, audio, and/or visual resources?

7. How could your research process be improved? guiding: Can you identify areas of the research process where you become frustrated or confused? Are there resources you use that you find difficult to navigate?

8. What role do you think the library could play in supporting your research? guiding: Have you ever used library resources or consulted with a librarian during research? Has there ever been information needed for a project that you could not find? 


\section{Notes}

1. Thomas K. Hagood, A History of Dance in American Higher Education: Dance and the American University (Lewiston, N.Y.: The Edwin Mellen Press, 2000), 100.

2. Ibid., 104-05.

3. Ibid., 111.

4. Wendy Oliver, Dance in Higher Education (Reston, Va.: American Alliance for Health, Physical Education, Recreation, and Dance, 1992), 2.

5. Gertrude Lippincott, "Report of the Arts in Government, Education, Community, 1965," Impulse: Annual of Contemporary Dance (1965): 8.

6. College Navigator, National Center for Education Statistics, available online at https://nces. ed.gov/collegenavigator/? $\mathrm{s}=$ all $\& \mathrm{p}=50.0302+50.0301+50.0399$ [accessed 16 September 2015] .

7. Dawn M. Grattino, "A Survey of the Information-Seeking Practices of Dance Professionals in Ohio" (master's thesis, Kent State University, 1996).

8. Ibid., 19-21.

9. Ibid., 26.

10. Ibid., 27.

11. Ann Medaille, "Creativity and Craft: The Information-Seeking Behavior of Theatre Artists," Journal of Documentation 66, no. 3 (2010): 339.

12. Francesca Marini, "Archivists, Librarians, and Theatre Research," Archivaria 63 (2007): 7-33.

13. Ibid., 19.

14. MaryBeth Meszaros, "A Theatre Scholar-Artist Prepares: Information Behavior of the Theatre Researcher," Advances in Library Administration and Organization 29 (2010): 209.

15. Bonnie Reed and Donald R. Tanner, "Information Needs and Library Services for the Fine Arts Faculty," Journal of Academic Librarianship 27, no. 3 (2001): 231.

16. Ibid., 231-32.

17. Kirstin Dougan, "Information Seeking Behaviors of Music Students," Reference Services Review 41, no. 4 (2012): 558-73; Kirstin Dougan, "Finding the Right Notes: An Observational Study of Score and Recording Seeking Behaviors of Music Students," Journal of Academic Librarianship 41, no. 1 (2015): 61-67.

18. Katie Lai, "How Are Our Undergraduates Using YouTube? A Survey of Music Students' Use of YouTube and the Library's Multimedia Collection," Music Reference Services Quarterly 16, no. 4 (2013): 207.

19. Joe C. Clark, "Format Preferences of Performing Arts Students," Journal of Academic Librarianship 39, no. 3 (2013): 297-307.

20. Ibid., 300-03.

21. Christine D. Brown, "Straddling the Humanities and Social Sciences: The Research Process of Music Scholars," Library \& Information Science Research 24, no. 1 (2002): 73-94.

22. Katie Lai and Kylie Chan, "Do You Know Your Music Users' Needs? A Library User Survey that Helps Enhance a User-Centered Music Collection," Journal of Academic Librarianship 36, no. 1 (2010): 66 .

23. Chern Li Liew and Siong Ngor Ng, "Beyond the Notes: A Qualitative Study of the Information-Seeking Behavior of Ethnomusicologists," Journal of Academic Librarianship 32, no. 1 (2006): 62.

24. Ibid., 66.

25. Kirstin Dougan, "'YouTube Has Changed Everything?' Music Faculty, Librarians, and Their Use and Perceptions of YouTube," College and Research Libraries 75, no. 4 (July 2014): 585.

26. Ibid., 586.

27. "The University of the Arts," College Navigator, National Center for Education Statistics, available online at http://nces.ed.gov/collegenavigator/? $\mathrm{s}=\mathrm{all} \& \mathrm{p}=50.0302+50.0399+50.0301 \& p g=1$ $5 \& i d=215105 \#$ programs [accessed 25 May 2015].

28. "Department of Dance Snapshot," College of Arts and Sciences, The Ohio State University, available online at http://artsandsciences.osu.edu/dance_snapshot [accessed 25 May 2015].

29. Interview by Shannon Marie Robinson, November 18, 2014.

30. Interview by Shannon Marie Robinson, May 29, 2014.

31. Interview by Shannon Marie Robinson, November 21, 2014.

32. Interview by Shannon Marie Robinson, July 14, 2014.

33. Interview by Shannon Marie Robinson, December 10, 2014.

34. Interview by Shannon Marie Robinson, May 29, 2014.

35. Interview by Shannon Marie Robinson, February 6, 2015.

36. Interview by Shannon Marie Robinson, October 24, 2014.

37. Interview by Shannon Marie Robinson, November 3, 2014. 
38. Interview by Shannon Marie Robinson, February 6, 2015.

39. Interview by Shannon Marie Robinson, May 29, 2014.

40. Interview by Shannon Marie Robinson, June 6, 2014.

41. Interview by Shannon Marie Robinson, November 21, 2014.

42. Interview by Shannon Marie Robinson, December 10, 2014.

43. Interview by Shannon Marie Robinson, February 6, 2015.

44. Interview by Shannon Marie Robinson, June 18, 2014.

45. Interview by Shannon Marie Robinson, October 24, 2014.

46. Medaille, "Creativity and Craft," 334.

47. Michael R. Olsson, "All the World's a Stage: The Information Practices and Sense-Making of Theatre Professionals," Libri 60 (Sept. 2010): 246.

48. "Conference 2013: Decentering Dance Studies: Moving in New Global Orders," Society of Dance History Scholars, available online at https://sdhs.org/conference2013nov-welcome [accessed 19 December 2015].

49. "Conference 2014: Writing Dancing/Dancing Writing," Society of Dance History Scholars, available online at https://sdhs.org/conference2014-welcome [accessed 19 December 2015].

50. "CORD + SDHS 2016," The Congress on Research and Dance and the Society for Dance History Scholars, available online at http://sdhscordconference.wildapricot.org/ [accessed 19 December 2015].

51. Meszaros, "A Theatre Scholar-Artist Prepares," 207.

52. Olsson, "All the World's a Stage," 256.

53. Medaille, "Creativity and Craft," 335.

54. Meszaros, "A Theatre Scholar-Artist Prepares," 207.

55. Dougan, "YouTube Has Changed Everything?" 575-89.

56. Interview by Shannon Marie Robinson, May 29, 2014.

57. Interview by Shannon Marie Robinson, June 18, 2014.

58. Interviews by Shannon Marie Robinson, October 24, 2014, and February 6, 2015.

59. Veronica Dittman, "A New York Dancer," in The Body Eclectic: Evolving Practices in Dance Training, eds. Melanie Bales and Rebecca Nettl-Fiol (Urbana, Ill.: University of Chicago Press, 2008), 24.

60. Ibid.

61. Marini, "Archivists, Librarians, and Theatre Research," 24.

62. Jan Van Dyke. "Questioning Trends in University Dance," Journal of Dance Education 12 (2012): 35 .

63. Marcia J. Bates, "Learning about the Information Seeking of Interdisciplinary Scholars and Students," Library Trends 45, no. 2 (Fall 1996): 156.

64. Don Spanner, "Border Crossings: Understanding the Cultural and Informational Dilemmas of Interdisciplinary Scholars," Journal of Academic Librarianship 27, no. 5 (Sept. 2001): 353.

65. Ibid., 354-65.

66. Ibid., 358. 161.

67. Bates, "Learning about the Information Seeking of Interdisciplinary Scholars and Students,"

68. Jeffrey A. Knapp, "Plugging the 'Whole': Librarians as Interdisciplinary Facilitators," Library Review 61, no. 3 (2012): 208.

69. Nena Couch, "Dance Collections," in Managing Performing Arts Collections in Academic and Public Libraries, ed. Carolyn A. Sheehy (Westport, Conn.: Greenwood Press, 1994), 51.

70. Eugenia Kim, "An Artist's Digital Preservation Toolkit: Dance as a Case Study for Capturing and Sharing the Creation Process," Art Documentation 31 (Fall 2012): 219-34. 159.

71. Bates, "Learning about the Information Seeking of Interdisciplinary Scholars and Students,"

72. Ibid., 162.

73. Knapp, "Plugging the 'Whole,'” 208.

74. Ibid., 209. 31.

75. Grattino, "A Survey of the Information-Seeking Practices of Dance Professionals in Ohio," 